\title{
Nutritional evaluation of mixed wheat-faba bean pasta in growing rats: impact of protein source and drying temperature on protein digestibility and retention
}

\author{
Karima Laleg ${ }^{1}$, Jérôme Salles ${ }^{1,2}$, Alexandre Berry ${ }^{1,2}$, Christophe Giraudet ${ }^{1,2}$, Véronique Patrac ${ }^{1,2}$, \\ Christelle Guillet $^{1,2}$, Philippe Denis ${ }^{1,3}$, Frédéric J. Tessier ${ }^{4}$, Axel Guilbaud ${ }^{4}$, Michael Howsam ${ }^{4}$, \\ Yves Boirie $^{2,5}$, Valérie Micard ${ }^{6 *}$ and Stéphane Walrand ${ }^{1,2_{*}}$ \\ ${ }^{1}$ INRA, UMR1019, UNH, CRNH Auvergne, 63009 Clermont-Ferrand, France \\ ${ }^{2}$ Université Clermont Auvergne, INRA, Unité de Nutrition Humaine, CRNH Auvergne, 63000 Clermont-Ferrand, France \\ ${ }^{3}$ Université Clermont Auvergne, INRA, Unité de Nutrition Humaine, Installation Expérimentale de Nutrition, CRNH Auvergne, \\ 63000 Clermont-Ferrand, France \\ ${ }^{4}$ Université de Lille, Inserm, CHU Lille, U995 - LIRIC - Lille Inflammation Research International Center, 59000 Lille, France \\ ${ }^{5}$ CHU Clermont-Ferrand, Service de Nutrition Clinique, 63003 Clermont-Ferrand, France \\ ${ }^{6}$ Montpellier SupAgro, UMR 1208 Ingénierie des Agropolymères et Technologies Emergentes, Cirad, Inra, Montpellier SupAgro, \\ Université de Montpellier, 34060 Montpellier, France
}

(Submitted 22 June 2018 - Final revision received 19 November 2018 - Accepted 19 November 2018 - First published online 30 January 2019)

\section{Abstract}

This study aimed to evaluate the nutritional value of pasta enriched with legume or wheat gluten proteins and dried at varying temperature. A total of four isonitrogenous experimental diets were produced using gluten powder/wheat semolina (6/94, g/g) pasta and faba bean flour/ wheat semolina $\left(35 / 65, \mathrm{~g} / \mathrm{g}\right.$ ) pasta dried at either $55^{\circ} \mathrm{C}$ (GLT and FLT, respectively) or $90^{\circ} \mathrm{C}$ (FVHT and GVHT, respectively). Experimental diets were fed to ten 1-month-old Wistar rats (body weight=176 ( markers were measured and compared with an isonitrogenous casein diet (CD). The enrichment with faba bean increased the lysine, threonine and branched amino acids by 97, 23 and 10\%, respectively. Protein utilisation also increased by $75 \%(P<0 \cdot 01)$ in FLT in comparison to GLT diet, without any effect on the corrected faecal digestibility $(P>0.05)$. Faba bean pasta diets' corrected protein digestibility and utilisation was only 3.5 and $9 \%$, respectively, lower than the CD. Growth rate, blood composition and muscle weights were not generally different with faba bean pasta diets compared with CD. Corrected protein digestibility was $3 \%$ lower in GVHT than GLT, which may be associated with greater carboxymethyllysine. This study in growing rats clearly indicates improvement in growth performance of rats fed legume-enriched pasta diet compared with rats fed gluten-wheat pasta diet, regardless of pasta drying temperature. This means faba bean flour can be used to improve the protein quality and quantity of pasta.

\section{Key words: Faba bean pasta: Drying temperature: Protein digestion: Protein retention: Protein structure}

Proteins are fundamental macronutrients in human and animal diet. Their primary function is to provide amino acids required for growth and maintenance of body tissue after digestive hydrolysis. Nutritional value of proteins varies according to their essential/non-essential amino acid composition, total digestion and rate of digestion in the gastrointestinal tract and the body's utilisation of the absorbed minimally oxidised amino acids ${ }^{(1,2)}$. Nutritional value of proteins is highly dependent on food component and processing conditions.
Animal products, chiefly meat, are a natural part of human diet recognised as a source of high-quantity, high-quality protein. Meat provides $16 \cdot 3-23.3 \mathrm{~g} / 100 \mathrm{~g} \operatorname{protein}^{(3)}$ with a good essential amino acid profile $\mathrm{e}^{(1,4)}$. Meat supplied $40 \%$ of humandiet protein in the world in 2013 (FAOSTAT, 2017). Meat consumption reached $34 \mathrm{~kg} /$ capita per year in 2013-2015 and is projected to increase by $6.5 \%$ in developed countries by $2025^{(5)}$. However, it is recommended to decrease meat consumption, due

Abbreviations: ATTD, apparent total tract digestibility; BV, biological value; CD, control diet; CFD, corrected faecal digestibility; CML, carboxymethyllysine; FLT, diet based on faba bean-wheat pasta dried at low temperature; FN, faecal nitrogen; FVHT, diet based on faba bean-wheat pasta dried at very high temperature; GLT, diet based on gluten-wheat pasta dried at low temperature; GVHT, diet based on gluten-wheat pasta dried at very high temperature; LM, lean mass; LT, low temperature; MCP-1, monocyte chemoattractant protein-1; NI, nitrogen intake; NPU, net protein utilisation; PFD, protein-free diet; UN, urinary nitrogen; VHT, very high temperature. 
to adverse effects of excessive intake on the environment ${ }^{(6)}$ and on health, notably an increased risk of $\mathrm{CVD}^{(7)}$.

This context has spurred growing interest in the development and production of vegetable-based protein foods that are easy to prepare, rich in good quality proteins and appreciated by consumers. Pasta, a highly popular product, partly meets these requirements. It is consumed worldwide and widely appreciated as a relatively inexpensive, easy-to-prepare, long-shelflife food staple. From a nutritional point of view, dry wheat pasta is a source of protein (12-13\%) and slowly digestible carbohydrates $(28 \%)^{(8)}$ that result in a low glycaemic index ${ }^{(9,10)}$. Despite this valuable nutritional quality, pasta - like most cereal products - is deficient in lysine and threonine ${ }^{(11)}$. Furthermore, it generally has lower protein content than animal products (around $4 \%$ protein in cooked pasta). Several studies have been carried out to improve the nutritional quality of pasta by incorporating non-traditional ingredients such as legume flours ${ }^{(11-14)}$. Legumes are a valuable source of dietary proteins $(20-40 \%)^{(15)}$. They contain $11-20 \%(w / w)$ resistant starch and are rich in slowly digestible carbohydrates ${ }^{(16)}$. In addition, legumes are rich in lysine and have a complementary amino acid profile to wheat proteins ${ }^{(15)}$. We have recently shown that the incorporation of $35 \%$ faba bean flour increased pasta protein content and enhanced lysine score by $52 \%$ in comparison to classical wheat pasta ${ }^{(11)}$. Enrichment with legume (faba bean) was also reported to increase the in vitro digestibility of the protein fraction, due to a specific weaker structure of the pasta protein ${ }^{(11)}$.

Besides pasta composition, variation in the process parameters, notably drying temperature, was also reported to affect pasta protein digestibility due to a modification of its protein network structure ${ }^{(17,18)}$. Industry pasta makers generally dry the pasta at high temperature $\left(65-94^{\circ} \mathrm{C}\right)$ to save time and energy. High-temperature drying was also shown to improve the technological quality (resilience and overall integrity) of legumeenriched pasta ${ }^{(19)}$. However, applying temperatures higher than $85^{\circ} \mathrm{C}$ strongly aggregates the component proteins, leading to lower in vitro protein digestibility. This phenomenon is not observed when pasta is dried at low temperature (LT) ${ }^{(17,18)}$

There is little data on the impact of the enrichment of pasta with legumes on in vivo protein digestibility ${ }^{(13,14,20)}$, and no data available on the effect of both improving protein composition and using different drying temperatures on the in vivo digestibility and nutritional value of pasta proteins. To address this gap, this study in growing rats aimed to compare the nutritional value and degree of protein digestibility and retention of mixed legume (faba bean)-wheat pasta dried at two drying temperatures (low and very high) with glutenwheat pasta and casein.

\section{Methods \\ Pasta manufacture and diet preparation}

Wheat (Triticum durum) semolina, wheat (Triticum aestivum)gluten powder and faba bean (Vicia faba) flour were provided by Panzani, Syral and GEMEF Industries, respectively. Composition of raw material is presented in Table 1 . The moisture content was determined in duplicate by drying at $130^{\circ} \mathrm{C}$ for $2 \mathrm{~h}$ in an oven ${ }^{(21)}$. The ash content was determined in duplicate by calcinations at $900^{\circ} \mathrm{C}$, according to the French method NF $03-720^{(22)}$. Starch content was determined in duplicate with an enzymatic assay kit (Megazyme Co.; AACC method 76-13.01) ${ }^{(23)}$. Crude protein content was determined in duplicate using the Kjeldahl procedure (digestion units: BÜCHI K-350, INST-0060-ANALYS; distillation unit: BÜCHI K-350, INST-XXXX-ANALYS; NF V 03-050, 1970) ${ }^{(24)}$ with a conversion factor of 5.7 for wheat and 6.25 for legume proteins. Fibres and lipids were determined by ISHA using the JORF (1986) method $^{(25)}$ and by Inovalys according to the NF ISO $6492^{(26)}$ procedure, respectively.

Pasta was manufactured and cooked as recently described by Laleg et al. ${ }^{(11)}$. Briefly, wheat semolina was enriched with $6 \%$ gluten powder or $35 \%$ faba bean flour to obtain the same protein content in the blend (approximately $15 \mathrm{~g} / 100 \mathrm{~g}$ ) and then processed into spaghetti form using a continuous pilotscale pasta extruder (Bassano). All spaghettis were dried at LT $\left(55^{\circ} \mathrm{C}, 70-90 \%\right.$ relative humidity, for $\left.15 \mathrm{~h}\right)$ or at very high temperature (VHT, $90^{\circ} \mathrm{C}, 70-90 \%$ relative humidity, for $3 \mathrm{~h}$ ) in a pilot-scale drier (AFREM).

To elaborate rat diets, pasta were cooked, dried at LT $\left(40^{\circ} \mathrm{C}\right.$, $70 \%$ relative humidity) for $24 \mathrm{~h}$ to reach approximately $12 \%$ moisture and then ground into a fine powder. A total of four experimental diets were then formulated by adding cellulose,

Table 1. Composition of raw materials*

\begin{tabular}{lccc}
\hline Composition of raw material $(\mathrm{g} / 100 \mathrm{~g})$ & Wheat semolina & Faba bean flour & Gluten powder \\
\hline Moisture & 14.6 & $10 \cdot 8$ & $5 \cdot 9$ \\
Protein & 11.2 & 21.4 & $75 \cdot 1$ \\
Starch & 66.4 & 51.4 & 9.9 \\
Ash & 1.1 & $2 \cdot 6$ & 0.9 \\
Fibres & 2.0 & 10.4 & $<1$ \\
Lipids & 1.5 & 1.7 & $<1$ \\
\hline
\end{tabular}

${ }^{*}$ The moisture content was determined in duplicate by drying at $130^{\circ} \mathrm{C}$, for $2 \mathrm{~h}$, in an oven ${ }^{(21)}$. Protein content was determined in duplicate using the Kjeldahl procedure (digestion units: BÜCHI K-350, INST-0060-ANALYS; distillation unit: BÜCHI K-350, INST-XXXX-ANALYS: NF V 03-050, 1970) ${ }^{(24)}$ with a conversion factor of 5.7 for wheat and 6.25 for legume proteins. Starch content was determined in duplicate with an enzymatic assay kit (Megazyme Co.; AACC method 76-13.01) ${ }^{(23)}$. The ash content was determined in duplicate by calcinations at $900^{\circ} \mathrm{C}$ according to the French method NF 03-720 (22). Fibres and lipids were determined by ISHA (Lonjumeau) using the JORF (1986) method ${ }^{(25)}$, and by Inovalys (Nantes) according to the NF ISO $6492^{(26)}$ procedure, respectively. Moisture: SD $<0.3$, protein: $\mathrm{SD}<0.06$, starch: $\mathrm{SD}<0.5$, ash: $\mathrm{SD}<0.01$. 
Table 2. Composition of the experimental and control diets

\begin{tabular}{|c|c|c|c|c|c|c|}
\hline \multirow[b]{2}{*}{ Ingredient $(\mathrm{g} / 100 \mathrm{~g})$} & \multicolumn{4}{|c|}{ Experimental diet } & \multirow[b]{2}{*}{$C D$} & \multirow[b]{2}{*}{ PFD } \\
\hline & FLT & FVHT & GLT & GVHT & & \\
\hline Pasta & $90 \cdot 0$ & $90 \cdot 0$ & $90 \cdot 0$ & $90 \cdot 0$ & 0.0 & 0.0 \\
\hline Casein & 0.0 & 0.0 & 0.0 & 0.0 & $15 \cdot 3$ & 0.0 \\
\hline Maize starch & 0.0 & 0.0 & 0.0 & 0.0 & $68 \cdot 1$ & $83 \cdot 4$ \\
\hline Cellulose & 0.9 & 0.9 & 1.0 & 1.0 & $6 \cdot 1$ & $6 \cdot 1$ \\
\hline Soya fat & 4.6 & 4.6 & 4.5 & 4.5 & $6 \cdot 0$ & $6 \cdot 0$ \\
\hline Minerals and vitamins & 4.5 & 4.5 & 4.5 & 4.5 & 4.5 & 4.5 \\
\hline Total & $100 \cdot 0$ & $100 \cdot 0$ & $100 \cdot 0$ & $100 \cdot 0$ & $100 \cdot 0$ & $100 \cdot 0$ \\
\hline \multicolumn{7}{|c|}{ Nutritional value of the diet $(\mathrm{g} / 100 \mathrm{~g})^{*}$} \\
\hline Protein & $14 \cdot 1$ & $14 \cdot 2$ & $14 \cdot 1$ & $14 \cdot 0$ & $14 \cdot 1$ & 0.2 \\
\hline Starch & $57 \cdot 1$ & $56 \cdot 7$ & $57 \cdot 2$ & 58.6 & $58 \cdot 4$ & $72 \cdot 2$ \\
\hline Fibres & $6 \cdot 6$ & $5 \cdot 2$ & 4.6 & $2 \cdot 8$ & $6 \cdot 6$ & $5 \cdot 7$ \\
\hline Lipid & $5 \cdot 3$ & $5 \cdot 8$ & 5.5 & $5 \cdot 0$ & $5 \cdot 3$ & 5.7 \\
\hline Energy $(\mathrm{kJ} / 100 \mathrm{~g})$ & 1503 & 1495 & 1478 & 1449 & 1524 & 1524 \\
\hline \multicolumn{7}{|c|}{ 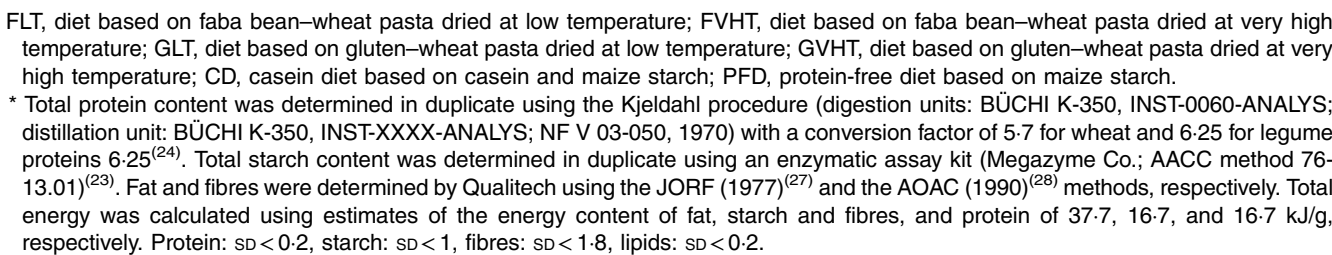 } \\
\hline
\end{tabular}

soya fat and mineral and vitamin mix to pasta powders (Table 2):

FLT diet: based on faba bean-wheat pasta dried at LT FVHT diet: based on faba bean-wheat pasta dried at VHT GLT diet: based on gluten-wheat pasta dried at LT GVHT diet: based on gluten-wheat pasta dried at VHT

These diets were compared with a control diet based on casein and maize starch (CD). In addition, a protein-free diet (PFD) mainly made of maize starch was studied (Table 2). This diet was used to estimate the endogenous and bacterial faecal N (EBFN) and the endogenous urinary $\mathrm{N}$ (EUN) of rats ( $\mathrm{N}$ loss in faeces and urine that are not related to the $\mathrm{N}$ content of the food).

Total starch content was determined in each diet in duplicate using an enzymatic assay kit (Megazyme Co.; AACC method 76-13.01) ${ }^{(23)}$. Crude protein content was determined in duplicate using the Kjeldahl procedure (digestion units: BÜCHI K-350, INST-0060-ANALYS; distillation unit: BÜCHI K-350, INST-XXXX-ANALYS; NF V 03-050, 1970) ${ }^{(24)}$ with a conversion factor of 5.7 for wheat and 6.25 for legume proteins. Fat and fibres were determined by Qualitech using the JORF (1977) ${ }^{(27)}$ and the AOAC (1990) $)^{(28)}$ methods, respectively. Total energy was calculated using the estimates of the energy content of fat, starch and fibres, and protein of $37 \cdot 7,16 \cdot 7$, and $16 \cdot 7 \mathrm{~kJ} / \mathrm{g}$, respectively. The composition of all experimental diets is presented in Table 2 . All diets provided the same amount of energy content (1495 (SEM 29) kJ/100 g) and proteins (14.1 (SEM 0.1) g/100g diet), except for the PFD (Table 2). The common portion size of uncooked pasta for humans is $100 \mathrm{~g}$ (approximately $280 \mathrm{~g}$ of cooked pasta). It provides approximately $15 \mathrm{~g}$ of protein. This protein quantity is 3-fold higher than that eaten by rats (approximately $4 \mathrm{~g} / \mathrm{d}$ ). All diets were subjected to amino acid and carboxymethyllysine (CML) determinations. Amino acid profiles ( $\mathrm{mg} / \mathrm{g}$ protein) were determined by Agrobio according to the EC Regulation 152/2009 method (2009) ${ }^{(29)}$, whereas CML was determined using the method developed by Niquet-Leridon \& Tessier ${ }^{(30)}$.

\section{Biological assays}

Ethical considerations. All animal procedures were approved by the institution's animal welfare committee (Comité d'Ethique en Matière d'Expérimentation Animale Auvergne; permit number: C2EA-02) and conducted in accordance with European guidelines on the care and use of laboratory animals (201063UE). The animals were housed in the research unit's own animal facilities (accreditation no. C6334514). At the end of the experiment, the rats were killed under isoflurane anaesthesia. Every effort was taken to minimise animal suffering.

\section{Experimental design}

In all, 1-month-old male Wistar rats ( $n$ 60, body weight $=176$ (SEM 15) g) were purchased from JANVIER, and housed in individual cages in an environmentally controlled room (temperature $22 \cdot 0 \pm 0 \cdot 8^{\circ} \mathrm{C}$, humidity $50 \pm 5 \%$, and $12 / 24 \mathrm{~h}$ light cycle). The rats had ad libitum access to chow and water. The rats were fed a CD during the 2-week acclimatisation period (AIN-93M, safe diets) before the study began. A total of sixty rats were randomly allotted to one of the six diets, for a total of ten animals per diet. Each group received ad libitum one experimental diet (GLT, GVHT, FLT or FVHT), CD or PFD. The study lasted $21 \mathrm{~d}$, during which rat food intake and weight gain were recorded every week. During the last $4 \mathrm{~d}$, rats were transferred into metabolic cages where food intake was weighed every day. Faeces and urine were also collected, weighed and then stored at $4^{\circ} \mathrm{C}$ until $\mathrm{N}$ determination at LaSalle (Bauvais), according to the Dumas method. At the end of the experiment, the rats were fasted for $12 \mathrm{~h}$ before being killed by decapitation. Blood samples were collected after decapitation into EDTA tubes (Venosafe $^{\oplus}$ ) and centrifuged at $1300 \mathrm{~g}$ for $10 \mathrm{~min}$ at $4^{\circ} \mathrm{C}$ to separate the plasma, which was then snap-frozen in liquid $\mathrm{N}_{2}$ and stored at $80^{\circ} \mathrm{C}$ until analysis. Blood was also collected into dry tubes 
(Venosafe $^{\oplus}$ ) and, after incubation for $20 \mathrm{~min}$ at room temperature, centrifuged at $1300 \mathrm{~g}$ for $10 \mathrm{~min}$ at $4^{\circ} \mathrm{C}$ (Jouan GR 412, DJB Labcare), to separate the serum, which was then snap-frozen in liquid $\mathrm{N}_{2}$ and stored at $-80^{\circ} \mathrm{C}$ until analysis.

Immediately after killing, the plantaris, soleus and tibialis muscles were removed from each side. Liver, peri-renal adipose tissue (PAT) and subcutaneous adipose tissue (SAT) were also collected. All tissues were weighed, frozen in liquid $\mathrm{N}_{2}$ and stored at $-80^{\circ} \mathrm{C}$ until analysis.

\section{Body weight and body composition}

Body weight was recorded at the beginning and end of the experiment. Body composition (lean mass (LM) and fat mass (FM)) of each rat was determined at the beginning and end of the experiment by MRI using Echo MRI (Echo Medical Systems). The results were expressed as percentage of body weight.

\section{Protein quality evaluation of treatments diets}

Rate of growth $(\mathrm{g} / \mathrm{d})$ was calculated as the weight gain between the beginning and end of the study ratioed to number of study days. Food and protein efficiency were calculated according to Proll et al. ${ }^{(31)}$ by the equations:

Food efficiency $=\frac{\text { Rate of growth }}{\text { Food intake }}(\mathrm{g}$ of weight gain $/ \mathrm{g}$ food intake $)$

Protein efficiency

$$
=\frac{\text { Rate of growth }}{\text { Protein intake }}(\mathrm{g} \text { of weight gain } / \mathrm{g} \text { protein intake })
$$

Protein quality of each diet was evaluated. Apparent total tract digestibility (ATTD), corrected faecal digestibility (CFD), net protein utilisation (NPU) and biological value (BV) were calculated according to Proll et $a l^{(31)}$ using the following equations:

$$
\begin{gathered}
\operatorname{ADF}(\%)=\frac{\mathrm{NI}-\mathrm{FN}}{\mathrm{NI}} \times 100 \\
\mathrm{CFD}(\%)=\frac{\mathrm{NI}-(\mathrm{FN}-\mathrm{EBFN})}{\mathrm{NI}} \times 100 \\
\mathrm{NPU}(\%)=\frac{\mathrm{NI}-(\mathrm{FN}+\mathrm{UN})+\mathrm{EBFN}+\mathrm{EUN}}{\mathrm{NI}} \times 100 \\
\mathrm{BV}(\%)=\frac{\mathrm{NPU}}{\mathrm{CFD}} \times 100
\end{gathered}
$$

EBFN is determined using the faecal $\mathrm{N}$ of PFD-group rats, EUN is determined using the urinary $\mathrm{N}$ of PFD-group rats, $\mathrm{FN}$ is the faecal $\mathrm{N}, \mathrm{NI}$ is the $\mathrm{N}$ intake and $\mathrm{UN}$ is the urinary $\mathrm{N}$.

\section{Biochemical analyses}

Tissue protein content was measured using a Micro BCA Protein Assay Kit (Thermo Fischer Scientific), according to the manufacturer's instructions. Blood glucose, NEFA, total cholesterol,
TAG, albumins and total proteins were measured using a Konelab 20 chemical analyser (Thermo Scientific). Plasma inflammatory markers, that is, monocyte chemoattractant protein-1 (MCP-1), fibrinogen, and orosomucoid, and plasma metabolic markers, that is, insulin, adiponectin and leptin were measured using an ELISA kit (PromoKine), according to the manufacturer's instructions.

\section{Statistical analysis}

Individual rat was considered as experimental unit. The sample size was calculated for an expected difference of $20-25 \%$ for corrected faecal protein digestibility between the control (casein) group and the gluten pasta diet group. A variance of $10 \%$ was considered according to the previous studies ${ }^{(13,20)}$ for the selected parameter (corrected faecal protein digestibility). The type I error $(\alpha)$ was set at $5 \%$, the type II error $(\beta)$ was set at $5 \%$, leading to $95 \%$ power. All analyses were performed using Statistica 8.0 software. All parameters were first analysed for normality. All data were tested by ANOVA with one factor: diet (one-way ANOVA), followed by a Fisher's least significant difference test to compare means at the $5 \%$ significance level. Tendency towards statistical significance is considered if $0 \cdot 05<P<0 \cdot 1$. The specific relationships between plasma (inflammatory and hormones) markers and metabolic markers, body weight and body composition were evaluated using Pearson's correlation coefficient with 95\% CI. In addition, all data on pasta diets (FLT, FVHT, GLT and GVHT) were subjected to two-way ANOVA using 'formulation' (faba bean-wheat or gluten-wheat) and 'drying' (LT or VHT) as factors. These results are given in the online Supplementary materials.

\section{Results}

\section{Amino acid composition of diets}

Table 3 reports the amino acid composition of diets. Essential amino acid profile differed considerably according to the protein source. All essential amino acid contents were lower in GLT compared with $\mathrm{CD}$, notably lysine, threonine and branched amino acids. Among branched amino acids, leucine was $20 \%$ lower in GLT compared with CD. In FLT, the enrichment with faba bean increased the lysine content by $97 \%$, threonine content by $23 \%$ and branched amino acid content by $10 \%$, in comparison to GLT. Leucine content was increased by $7 \%$, whereas the sulphur amino acid content decreased by $27 \%$ in comparison to GLT. VHT drying gave the same pattern of results. In addition, lysine content was 6 and $4 \%$ lower, and tryptophan content was 17 and 7\% lower in GVHT and FVHT diets compared with GLT and FLT diets, respectively. CML was $98 \%$ higher in FLT compared with GLT diets. The use of VHT increased CML by $67 \%$ in faba bean pasta diets and by $79 \%$ in gluten pasta diets in comparison to LT.

\section{Impact of the type of diet on growth parameters and body composition}

Throughout the study, rats consumed an equivalent amount of diet (Table 4). Table 4 reports food efficiency, protein 
Table 3. Essential amino acid profile and carboxymethyl-lysine (CML) composition of the diets

\begin{tabular}{|c|c|c|c|c|c|}
\hline Amino acids (mg/g of protein) & FLT & FVHT & GLT & GVHT & CD \\
\hline His & $25 \cdot 8$ & $25 \cdot 4$ & 21.9 & $21 \cdot 8$ & $26 \cdot 4$ \\
\hline Ile & $39 \cdot 2$ & 39.9 & 36.5 & 37.3 & 48.9 \\
\hline Leu & $78 \cdot 4$ & $80 \cdot 0$ & 73.6 & $72 \cdot 6$ & 88.4 \\
\hline Val & $46 \cdot 9$ & $48 \cdot 0$ & 39.9 & $40 \cdot 7$ & $66 \cdot 5$ \\
\hline Lys & $37 \cdot 4$ & 35.9 & $19 \cdot 0$ & $17 \cdot 9$ & 75.5 \\
\hline Sulphur-amino acids & $32 \cdot 1$ & $31 \cdot 7$ & 43.8 & $44 \cdot 0$ & $46 \cdot 1$ \\
\hline Aromatic amino acids & $77 \cdot 4$ & $77 \cdot 2$ & $75 \cdot 4$ & $76 \cdot 2$ & 88.9 \\
\hline Thr & $33 \cdot 1$ & $33 \cdot 7$ & 26.9 & $26 \cdot 4$ & 39.8 \\
\hline Trp & 11.4 & $10 \cdot 6$ & $10 \cdot 9$ & $9 \cdot 1$ & $\mathrm{~N} / \mathrm{A}$ \\
\hline Branched amino acids & 164.5 & 167.9 & $150 \cdot 0$ & $150 \cdot 6$ & 203.8 \\
\hline CML ( $\mu \mathrm{g} / \mathrm{g}$ protein)† & 212 & 354 & 107 & 192 & $\mathrm{~N} / \mathrm{A}$ \\
\hline
\end{tabular}

FLT, diet based on faba bean-wheat pasta dried at low temperature; FVHT, diet based on faba bean-wheat pasta dried at very high temperature; GLT, diet based on gluten-wheat pasta dried at low temperature; GVHT, diet based on gluten-wheat pasta dried at very high temperature; $C D$, casein diet based on casein and maize starch; N/A, not analysed.

* Amino acids were determined by Agrobio (Rennes) according to the EC Regulation 152/2009 (2009) method ${ }^{(29)}$. The relative standard deviation of the method is lower than $3 \%$.

† CML was determined by liquid chromatography-MS/MS according to the method developed by Niquet-Léridon \& Tessier ${ }^{(30)}$. The relative standard deviation of the method is lower than $5 \%$.

Table 4. Food intake, food and protein efficiency, rate of growth, body weight and body composition of rats fed treatment diets (Mean values with their standard errors, $n 10$ rats for all experiments)

\begin{tabular}{|c|c|c|c|c|c|c|c|}
\hline Diet & $\begin{array}{c}\text { Food intake } \\
(\mathrm{g} / \mathrm{d})^{*}\end{array}$ & $\begin{array}{l}\text { Food efficiency } \\
\text { (g gain/g intake) }^{*}\end{array}$ & $\begin{array}{l}\text { Protein efficiency } \\
{\text { (g gain/g intake })^{\star}}\end{array}$ & $\begin{array}{l}\text { Rate of growth } \\
(\mathrm{g} / \mathrm{d})^{*}\end{array}$ & $\begin{array}{l}\text { Body weight } \\
(\mathrm{g})^{*}\end{array}$ & $\begin{array}{c}\text { FM }(\% \text { body } \\
\text { weight }) \dagger\end{array}$ & $\begin{array}{c}\text { LM (\% body } \\
\text { weight }) \dagger\end{array}$ \\
\hline FLT & $28 \cdot 7^{a}$ & $0.33^{\mathrm{a}}$ & $2 \cdot 3^{a}$ & $9 \cdot 3^{a}$ & $327^{a}$ & $14 \cdot 1^{\mathrm{a}}$ & $78 \cdot 7^{b}$ \\
\hline FVHT & $29 \cdot 1^{\mathrm{a}}$ & $0.32^{\mathrm{a}}$ & $2 \cdot 3^{\mathrm{a}}$ & $9 \cdot 3^{\mathrm{a}}$ & $328^{a}$ & $15 \cdot 8^{\mathrm{a}}$ & $77 \cdot 2^{\mathrm{b}}$ \\
\hline GLT & $31 \cdot 2^{a}$ & $0 \cdot 18^{b}$ & $1 \cdot 3^{b}$ & $5 \cdot 4^{\mathrm{b}}$ & $257^{\mathrm{b}}$ & $14 \cdot 2^{a}$ & $78 \cdot 4^{b}$ \\
\hline GVHT & $28 \cdot 4^{a}$ & $0.17^{b}$ & $1 \cdot 2^{\mathrm{b}}$ & $4 \cdot 6^{\mathrm{b}}$ & $237^{\mathrm{b}}$ & $11 \cdot 2^{b}$ & $81 \cdot 3^{a}$ \\
\hline$C D$ & $27 \cdot 3^{a}$ & $0.33^{a}$ & $2 \cdot 3^{a}$ & $8 \cdot 9^{a}$ & $320^{a}$ & $9 \cdot 8^{b}$ & $82 \cdot 9^{a}$ \\
\hline Pooled SEM & $3 \cdot 1$ & 0.02 & 0.2 & 0.7 & 19 & $2 \cdot 0$ & 1.8 \\
\hline$P$ & NS & $<0.01$ & $<0.01$ & $<0.01$ & $<0.01$ & $<0.01$ & $<0.01$ \\
\hline
\end{tabular}

FM, fat mass; LM, lean mass; FLT, diet based on faba bean-wheat pasta dried at low temperature; FVHT, diet based on faba bean-wheat pasta dried at very high temperature; GLT, diet based on gluten-wheat pasta dried at low temperature; GVHT, diet based on gluten-wheat pasta dried at very high temperature; CD, casein diet based on casein and maize starch.

a,b Mean values within a column with unlike superscript letters were significantly different $(P<0.05)$.

* Food intake ( $\mathrm{g} / \mathrm{d}$ ) was measured every week. Body weight was recorded at the beginning and at the end of the experiment. Rate of growth ( $\mathrm{g} / \mathrm{d}$ ) was calculated as the weight gain between the beginning and the end of the study ratioed to the number of study days. Food efficiency ( $\mathrm{g}$ of weight gain/g food intake) was calculated using the equation ${ }^{(31)}$ : Food efficiency $=\frac{\text { Rate of growth }}{\text { Food intake }}$. Protein efficiency ( $g$ of weight gain $/ g$ protein intake) was calculated using the equation ${ }^{(31)}$ : Protein efficiency $=\frac{\text { Rate of growth }}{\text { Protein intake }}$. $\dagger \mathrm{LM}$ and FM were measured by MRI using Echo MRI (Echo Medical Systems).

efficiency, rate of growth and final body weight of the rats. Regardless of the drying temperature (LT or VHT), rats receiving a faba bean pasta diet were characterised by a $1 \cdot 7-2 \cdot 0$-fold higher food efficiency, protein efficiency and rate of growth, and a $1 \cdot 3$-fold higher body weight compared with rats receiving a diet composed of gluten pasta. FLT and FVHT were as food efficient and protein efficient as $\mathrm{CD}$. The rate of growth and body weight was not significantly different between rats fed faba bean pasta diet and CD. Rats fed GLT and GVHT diets were characterised by a 1.6-1.9-fold lower food efficiency, protein efficiency and rate of growth, and 1.3-fold lower body weight compared with rats fed $\mathrm{CD}$.

There was no difference in growth parameters of rats between LT and VHT drying regardless of the protein source (faba bean-wheat or gluten-wheat).

There were no significant differences between rats fed FLT and GLT in FM to body weight and LM to body weight ratios (Table 4), whereas rats fed GVHT had significantly lower FM and higher LM than their FVHT counterparts. Body composition of all rats fed pasta diets except GVHT was characterised by a higher FM to body weight ratio (44-61\%) and a lower LM to body weight ratio $(5-7 \%)$ than rats fed the $\mathrm{CD}$. A significant drying effect was observed only in the gluten pasta diet group, with $21 \%$ lower FM and $4 \%$ higher LM in GVHT than GLTfed rats.

Table 5 reports the muscle weight of each group. Regardless of pasta drying temperature, rats fed faba bean pasta diets had $27-34 \%$ heavier plantaris, $13-21 \%$ heavier tibialis anterior and $22-28 \%$ heavier soleus compared with rats fed gluten pasta diets. Rats fed faba bean pasta diets had generally a close muscle weight to rats fed $\mathrm{CD}$, except for soleus weight which was $13 \%$ lower in FVHT compared with CD. Conversely, rats fed with gluten pasta diets were characterised by significantly lower muscle weight (24, 23 and $20 \%$ for plantaris, tibialis and soleus, respectively) compared with $\mathrm{CD}$.

Rats fed FLT and FVHT had a $12 \%$ higher liver weight to body weight ratio compared with GLT and rats fed GVHT. Liver weight was 7 and $17 \%$ higher in rats fed CD than in rats fed faba bean and gluten pasta diets, respectively. There was no significant difference in PAT and SAT masses between rats fed FLT 
Table 5. Muscle, liver and adipose tissues (peri-renal and sub-cutaneous) weights of rats fed treatment diets (Mean values with their standard errors, $n 10$ rats for all experiments)

\begin{tabular}{lcccccc}
\hline Diet & Plantaris $(\mathrm{g})$ & Soleus $(\mathrm{g})$ & Tibialis $(\mathrm{g})$ & Liver $(\mathrm{g} / 100 \mathrm{~g}$ body weight) & PAT (g/100g body weight) & SAT (g/100 g body weight) \\
\hline FLT & $0.59^{\mathrm{a}}$ & $0.29^{\mathrm{a}, \mathrm{b}}$ & $1.05^{\mathrm{a}}$ & $3.00^{\mathrm{b}}$ & $1.12^{\mathrm{a}}$ & $1.38^{\mathrm{a}}$ \\
FVHT & $0.56^{\mathrm{a}}$ & $0.27^{\mathrm{b}}$ & $1.06^{\mathrm{a}}$ & $2.99^{\mathrm{b}}$ & $1.07^{\mathrm{a}}$ & $1.59^{\mathrm{a}}$ \\
GLT & $0.44^{\mathrm{b}}$ & $0.24^{\mathrm{c}}$ & $0.86^{\mathrm{b}}$ & $2.67^{\mathrm{c}}$ & $0.85^{\mathrm{b}}$ & $1.49^{\mathrm{a}}$ \\
GVHT & $0.44^{\mathrm{b}}$ & $0.24^{\mathrm{c}}$ & $0.83^{\mathrm{b}}$ & $2.68^{\mathrm{c}}$ & $0.74^{\mathrm{b}}$ & $1.37^{\mathrm{a}}$ \\
CD & $0.58^{\mathrm{a}}$ & $0.31^{\mathrm{a}}$ & $1.07^{\mathrm{a}}$ & $3.21^{\mathrm{a}}$ & 0.16 & $0.98^{\mathrm{b}}$ \\
Pooled SEM & 0.03 & 0.02 & 0.05 & 0.13 & $<0.01$ & 0.22 \\
$P$ & $<0.01$ & $<0.01$ & $<0.01$ & $<0.01$ & $<01$ \\
\hline
\end{tabular}

PAT, peri-renal adipose tissue; SAT, subcutaneous adipose tissue; FLT, diet based on faba bean-wheat pasta dried at low temperature; FVHT, diet based on faba bean-wheat pasta dried at very high temperature; GLT, diet based on gluten-wheat pasta dried at low temperature; GVHT, diet based on gluten-wheat pasta dried at very high temperature; CD, casein diet based on casein and maize starch.

a,b,c Mean values within a column with unlike superscript letters were significantly different $(P<0.05)$.

Table 6. Protein composition* of muscles (soleus, tibialis and plantaris) and liver of rats fed treatment diets (Mean values with their standard errors, $n 10$ rats for all experiments)

\begin{tabular}{lcccc}
\hline Diet & Soleus (\%) & Tibialis (\%) & Plantaris (\%) & Liver (\%) \\
\hline FLT & $14 \cdot 7^{\mathrm{a}}$ & $17 \cdot 8^{\mathrm{a}}$ & $17 \cdot 7^{\mathrm{a}}$ & $18 \cdot 8^{\mathrm{a}}$ \\
FVHT & $15 \cdot 3^{\mathrm{a}}$ & $16 \cdot 9^{\mathrm{a}}$ & $17 \cdot 1^{\mathrm{a}, \mathrm{b}}$ & $19 \cdot 7^{\mathrm{a}}$ \\
GLT & $14 \cdot 9^{\mathrm{a}}$ & $17 \cdot 6^{\mathrm{a}}$ & $15 \cdot 1^{\mathrm{b}}$ & $19 \cdot 3^{\mathrm{a}}$ \\
GVHT & $14 \cdot 9^{\mathrm{a}}$ & $17 \cdot 0^{\mathrm{a}}$ & $15 \cdot 4^{\mathrm{b}}$ & $19 \cdot 6^{\mathrm{a}}$ \\
CD & $15 \cdot 1^{\mathrm{a}}$ & $18 \cdot 1^{\mathrm{a}}$ & $15 \cdot 6^{\mathrm{b}}$ & $18 \cdot 9^{\mathrm{a}}$ \\
Pooled SEM & $1 \cdot 0$ & $1 \cdot 6$ & $1 \cdot 5$ & $1 \cdot 0$ \\
$P$ & $\mathrm{NS}$ & $\mathrm{NS}$ & $\mathrm{NS}$ & $\mathrm{NS}$ \\
\hline
\end{tabular}

FLT, diet based on faba bean-wheat pasta dried at low temperature; FVHT, diet based on faba bean-wheat pasta dried at very high temperature; GLT, diet based on gluten-wheat pasta dried at low temperature; GVHT, diet based on gluten-wheat pasta dried at very high temperature; $\mathrm{CD}$, casein diet based on casein and maize starch.

a,b Mean values within a column with unlike superscript letters were significantly different.

* Tissue protein content was measured using a Micro BCA protein assay kit.

and GLT. PAT and SAT were significantly higher in both FLT and GLT compared with rats fed CD.

There was no effect of drying temperature on any of the above parameters, other than a significant $21 \%$ lower PAT in rats fed GVHT compared with rats fed GLT.

\section{Tissue protein content}

Table 6 reports the rat muscle and liver protein contents. There were no significant differences between rat groups in protein content of soleus muscle, tibialis muscle and liver $(P=0 \cdot 6-0 \cdot 9)$. A faba bean pasta diet tended to increase the protein content of plantaris muscle compared with the other diets but without significant effect $(P=0 \cdot 07)$. There was no drying temperature effect on any of the muscle or liver protein contents.

\section{Protein quality evaluation of treatments diets}

Table 7 reports the FN and UN to NI. Regardless of drying temperature, rats fed faba bean pasta diet had higher FN (36-67\%) than rats fed gluten pasta diet. Rats fed CD and GLT were characterised by the lowest FN content. Drying temperatures only had an effect in rats fed gluten pasta diet, increasing FN loss by $22 \%$ in rats fed GVHT compared with GLT. UN was 32 and $22 \%$ lower in rats fed FLT and FVHT than in rats fed GLT and GVHT, respectively. Rats fed CD maintained the lowest UN content, which was $43-48 \%$ lower than in rats fed GLT and GVHT, and 24-26\% lower than in rats fed FLT and FVHT diet. There was no effect of temperature on UN regardless of the diet type.
The higher FN content of rats fed faba bean pasta diet led to a lower ATTD compared with rats fed gluten pasta diet (Table 7). All pasta diets except GLT resulted in a lower (4-8\%) ATTD compared with CD. Drying pasta at a VHT led to a significant decrease in the ATTD of rats fed gluten pasta diet (3\%) compared with LT drying, but no impact on faba bean pasta diet. CFD (Table 7) did not vary according to protein composition of the pasta diet but was decreased by $3-6 \%$ in rats fed pasta diet compared with $\mathrm{CD}$ rats. Rats fed GVHT had $3 \%$ reduced CFD of protein compared with rats fed GLT, but this was not the case for rats fed FLT and FVHT.

In accordance with the UN results, the NPU and BV (Table 7) were significantly increased (1.5-1.8-fold) in rats fed FLT and FVHT compared with rats fed GLT and GVHT diets, without any effect of drying temperature. Rats fed CD conserved the highest NPU and the best BV. Interestingly, rats fed the FLT diet had a $\mathrm{BV}$ that was close to rats fed the CD.

\section{Metabolic parameters}

Table 8 reports the recorded blood parameters. Regardless of the processing temperature, rats fed faba bean diet have $6.4 \%$ greater albumin and $11.7 \%$ greater total protein in the blood compared with rats fed gluten diet. There were no significant differences between rats fed faba bean pasta diet and rats fed CD in blood albumin and total protein concentrations, whereas rats fed gluten pasta diet had $7 \%$ lower blood albumin and 12-13\% lower total blood proteins compared with rats fed CD. Blood glucose was greater in rats fed FLT or FVHT compared with rats fed CD. There was no significant difference in glucose between rats fed GLT and GVHT and rats fed CD. 
Table 7. Evaluation of protein quality of treatment diets (Mean values with their standard errors, $n 10$ rats for all experiments)

\begin{tabular}{|c|c|c|c|c|c|c|}
\hline Diet & FN/NI $(g / g)^{\star}$ & UN/NI $(g / g)^{*}$ & ATTD $(\%)^{*}$ & CFD $(\%)^{*}$ & $\operatorname{NPU}(\%)^{\star}$ & $\mathrm{BV}(\%)^{*}$ \\
\hline FLT & $0.15^{a}$ & $0.51^{\mathrm{b}}$ & $85 \cdot 3^{c}$ & $98 \cdot 3^{b}$ & $76 \cdot 4^{b}$ & $77 \cdot 9^{a, b}$ \\
\hline FVHT & $0 \cdot 15^{\mathrm{a}}$ & $0.53^{b}$ & $85 \cdot 1^{\mathrm{c}}$ & $97 \cdot 2^{b, c}$ & $72 \cdot 3^{\mathrm{b}}$ & $74 \cdot 3^{b}$ \\
\hline GLT & $0.09^{c}$ & $0.75^{a}$ & $91 \cdot 1^{\mathrm{a}}$ & $98 \cdot 5^{\mathrm{b}}$ & $43 \cdot 7^{c}$ & $44 \cdot 3^{c}$ \\
\hline GVHT & $0 \cdot 11^{\mathrm{b}}$ & $0.68^{\mathrm{a}}$ & $88.5^{\mathrm{b}}$ & $95 \cdot 6^{c}$ & $46 \cdot 6^{\mathrm{C}}$ & $48 \cdot 7^{\mathrm{C}}$ \\
\hline$C D$ & $0.08^{c}$ & $0.39^{c}$ & $92 \cdot 0^{a}$ & $101.9^{a}$ & $83 \cdot 8^{a}$ & $82 \cdot 2^{a}$ \\
\hline Pooled SEM & 0.02 & 0.06 & 1.6 & $2 \cdot 1$ & $5 \cdot 7$ & 5.5 \\
\hline$P$ & $<0.01$ & $<0.05$ & $<0.01$ & $<0.01$ & $<0.01$ & $<0.01$ \\
\hline
\end{tabular}

FN, faecal N; NI, N intake; UN, urinary N; ATTD, apparent total tract digestibility; CFD, corrected faecal digestibility; NPU, net protein utilisation; BV, biological value; FLT, diet based on faba bean-wheat pasta dried at low temperature; FVHT, diet based on faba bean-wheat pasta dried at very high temperature; GLT, diet based on gluten-wheat pasta dried at low temperature; GVHT, diet based on gluten-wheat pasta dried at very high temperature; CD, casein diet based on casein and maize starch; EBFN, endogenous and bacterial faecal N; EUN, endogenous urinary $\mathrm{N}$.

a,b,c Mean values within a column with unlike superscript letters were significantly different $(P<0.05)$.

${ }^{*}$ FN and NU were measured according to the Dumas method, in triplicate for each rat. ATTD, CFD, NPU and BV were calculated according to Proll et al. ${ }^{(31)}$ using the equations:

$$
\begin{aligned}
& \operatorname{ATTD}(\%)=\frac{\mathrm{NI}-\mathrm{FN}}{\mathrm{NI}} \times 100 \\
& \mathrm{CFD}(\%)=\frac{\mathrm{NI}-(\mathrm{FN}-\mathrm{EBFN})}{\mathrm{NI}} \times 100 \\
& \mathrm{NPU}(\%)=\frac{\mathrm{NI}-(\mathrm{FN}+\mathrm{UN})+\mathrm{EBFN}+\mathrm{EUN}}{\mathrm{NI}} \times 100 \\
& \mathrm{BV}(\%)=\frac{\mathrm{NPU}}{\mathrm{CFD}} \times 100
\end{aligned}
$$

\begin{tabular}{|c|c|c|c|c|c|c|c|}
\hline Diet & Albumin $(g / l)^{*}$ & Total protein $(\mathrm{g} / \mathrm{l})^{*}$ & Glucose $(g / l)^{*}$ & Cholesterol $(\mathrm{g} / \mathrm{l})^{*}$ & TAG $(g / l)^{\star}$ & $\operatorname{NEFA}(\mathrm{mg} / \mathrm{l})^{\star}$ & Free glycerol $(\mathrm{mg} / \mathrm{l})^{\star}$ \\
\hline FLT & $33 \cdot 4^{\mathrm{a}}$ & $56 \cdot 4^{a}$ & $1.06^{a}$ & $0.74^{b}$ & $0.81^{a}$ & $276^{b}$ & $243^{a}$ \\
\hline FVHT & $33 \cdot 4^{\mathrm{a}}$ & $56 \cdot 1^{\mathrm{a}}$ & $1.04^{\mathrm{a}}$ & $0.74^{\mathrm{b}}$ & $0.85^{\mathrm{a}}$ & $299^{a, b}$ & $255^{\mathrm{a}}$ \\
\hline GLT & $31 \cdot 4^{b}$ & $50 \cdot 5^{b}$ & $0.99^{a, b}$ & $0.86^{a, b}$ & $0.43^{b}$ & $281^{b}$ & $243^{a}$ \\
\hline GVHT & $31 \cdot 3^{b}$ & $51 \cdot 2^{b}$ & $0.92^{\mathrm{b}}$ & $0.95^{\mathrm{a}}$ & $0.47^{b}$ & $331^{a}$ & $252^{a}$ \\
\hline CD & $33 \cdot 7^{\mathrm{a}}$ & $58 \cdot 3^{a}$ & $0.89^{b}$ & $0.54^{c}$ & $0 \cdot 70^{a, b}$ & $314^{a, b}$ & $236^{a}$ \\
\hline Pooled SEM & 0.8 & 1.9 & 0.08 & 0.12 & 0.19 & 38 & 29 \\
\hline$P$ & $<0.01$ & $<0.01$ & 0.01 & $<0.01$ & $<0.01$ & NS & NS \\
\hline
\end{tabular}

The EBFN and the EUN of rats were determined using the FN and the UN obtained from rats fed protein-free diet, respectively.

Table 8. Blood concentration of metabolic markers of rats fed treatment diets (Mean values with their standard errors, $n 10$ rats for all experiments)

FLT, diet based on faba bean-wheat pasta dried at low temperature; FVHT, diet based on faba bean-wheat pasta dried at very high temperature; GLT, diet based on gluten-wheat pasta dried at low temperature; GVHT, diet based on gluten-wheat pasta dried at very high temperature; CD, casein diet based on casein and maize starch.

a,b,c Mean values within a column with unlike superscript letters were significantly different $(P<0.05)$.

* Blood glucose, NEFA, total cholesterol, TAG, albumins and total proteins were measured using a Konelab 20 chemistry analyser (Thermo Scientific).

Cholesterol concentration was $37-76 \%$ higher in all rats fed pasta diets compared with rats fed CD. Interestingly, cholesterol concentration in rats fed FVHT was $22 \%$ lower compared with rats fed GVHT. There was no significant difference in blood TAG between rats fed pasta diet and rats fed CD. Blood TAG content was lowered by 88 and $80 \%$ in GLT and GVHT, respectively, compared with FLT and FVHT. There was no significant diet-type effect $(P>0.05)$ on blood NEFA and free glycerol. Drying temperature significantly decreased the blood NEFA in GVHT compared with GLT (online Supplementary Table S5). There was no drying temperature effect on any of the other parameters (albumin, total protein, glucose, cholesterol, TAG and free glycerol).

\section{Plasma and inflammatory markers}

The role of chronic inflammation in the degenerative diseases of modern society has stimulated research into the influence of diets on inflammatory markers ${ }^{(32)}$. Dietary pattern was reported to be one of the main strategies to reduce inflammation ${ }^{(33,34)}$. Legume consumption may contribute to reductions in C-reactive protein concentrations, a marker of systemic inflammation $^{(35)}$. Here, the inflammatory profiles resulting from legume, gluten or casein diets consumption were investigated.

Blood fibrinogen (Fig. 1(A)) were not significantly different in all rats $(P=0 \cdot 3)$. There was no significant correlation between fibrinogen and metabolic markers, body weight and composition. Blood orosomucoid (Fig. 1(B)) was $57-75 \%$ higher in rats fed faba bean pasta compared with rats fed gluten pasta diet and $\mathrm{CD}$. There was no difference in blood orosomucoid content between rats fed CD, GLT or GVHT diets. Orosomucoid content was significantly positively correlated with total body weight $(r$ 0.55), FM ( $r$ 0.59), blood glucose $(r$ 0.45) and blood TAG ( $r$ 0.50), and negatively correlated with LM $(r-0.59)$. MCP-1 (Fig. 1(C)) was at equivalent levels between rats fed faba bean pasta diet and CD. Rats fed GLT and GVHT had approximately $15 \%$ lower MCP-1 content compared with rats fed CD and faba bean pasta diet. MCP-1 was significantly correlated with body 
(A)

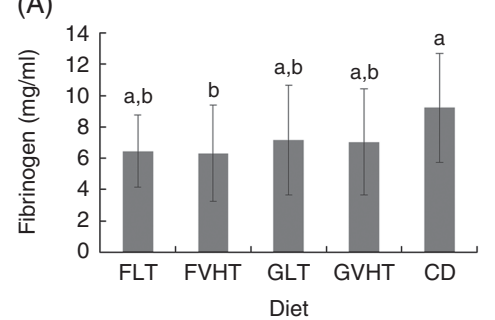

(D)

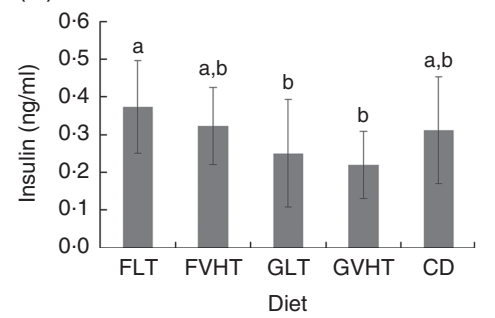

(B)

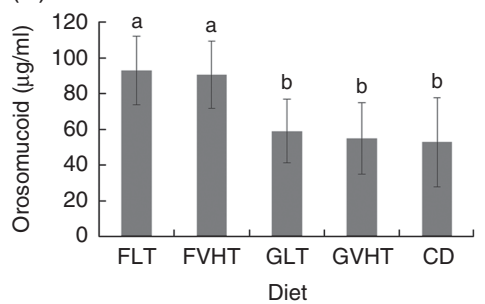

(E)

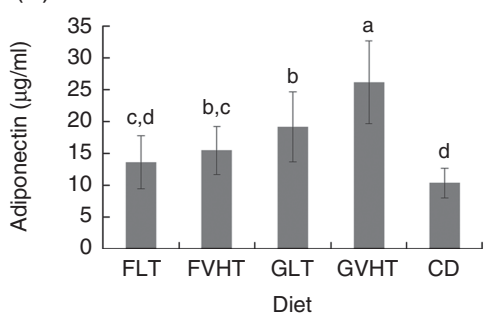

(C)

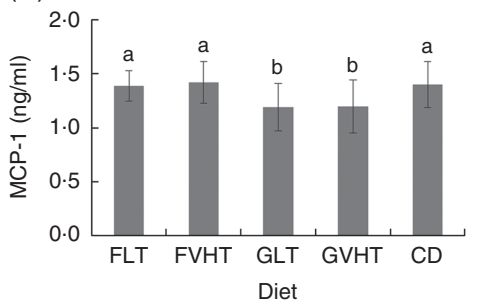

(F)

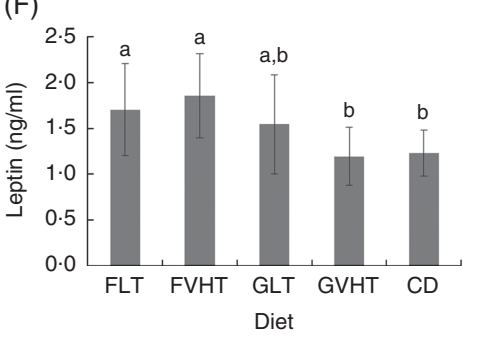

Fig. 1. Plasma markers of rats fed treatment diets. Diets FLT and FVHT are based on faba bean-wheat pasta dried at low temperature and very high temperature, respectively. Diets GLT and GVHT are based on gluten-wheat pasta dried at low temperature and high temperature, respectively. CD is casein diet based on casein and maize starch. (A) Fibrinogen, (B) orosomucoid, (C) monocyte chemoattractant protein-1 (MCP-1), (D) insulin, (E) adiponectin, (F) leptin. Values are means ( $n 10$ rats), with their standard errors represented by vertical bars. Analyses were performed using an ELISA kit (PromoKine), according to the manufacturer's instructions. ${ }^{a, b, c, d}$ Mean values with unlike letters were significantly different $(P<0.05)$.

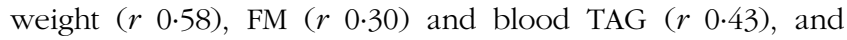
negatively correlated with blood cholesterol $(r-0 \cdot 34)$. There was no drying temperature effect on fibrinogen, orosomucoid and MCP-1 composition.

Blood insulin (Fig. 1(D)) was higher in rats fed FLT compared with rats fed GLT. There was no drying temperature effect on blood insulin. Overall, faba bean-enriched pasta diet led to a blood insulin level equivalent to $\mathrm{CD}$. Insulin was significantly positively correlated with body weight ( $r 0.63)$, FM ( $r 0.44)$, TAG ( $r$ 0.64), orosomucoid ( $r 0.50)$ and MCP-1 $(r 0.28)$ and negatively correlated with LM $(r-0.44)$. Adiponectin content was 29 and $41 \%$ lower under FLT and FVHT diets compared with GLT and GVHT diets (Fig. 1(E)). VHT drying led to a substantial $36 \%$ increase in adiponectin content in rats fed gluten pasta diet. Adiponectin contents were not significantly different in rats fed FLT and CD. Adiponectin was significantly positively correlated with cholesterol ( $r$ 0.49) and negatively correlated with body weight $(r-0 \cdot 54)$. Blood leptin concentrations (Fig. 1(F)) were not significantly different in rats fed FLT and GLT but significantly higher (55\%) in rats fed FVHT than GVHT rats. Blood leptin was higher in rats fed faba bean pasta diet compared with CD (38\% higher for FLT and $51 \%$ higher for FVHT). Leptin concentration was not significantly different in rats fed GLT and GVHT and rats fed CD. Blood leptin was significantly positively correlated with body weight $(r 0.54)$, FM $(r 0.81)$, blood TAG $(r 0.67)$, blood insulin ( $r$ 0.63), MCP-1 $(r$ 0.30) and orosomucoid $(r \quad 0.61)$, and significantly negatively correlated with LM $(r-0 \cdot 80)$. There was no significant effect of drying temperature on leptin.

\section{Discussion}

The primary objective of this study in growing rats was to assess the impact of a diet based on mixed wheat-faba bean pasta dried at $\mathrm{LT}\left(55^{\circ} \mathrm{C}\right)$ or $\mathrm{VHT}\left(99^{\circ} \mathrm{C}\right)$, on key indicators of dietary protein quality, body composition, tissue protein content and blood metabolic and inflammatory markers. Diets were composed of either plant proteins, that is, the classical gluten-wheat pasta and mixed faba bean-wheat pasta, or animal proteins, that is, casein, all delivering the same food protein content (approximately $14 \%)$. Casein diets were considered as controls. The pasta used in this study (gluten-wheat pasta and faba bean-wheat pasta) were subjected to the same multiscale structure determination as in our previous work ${ }^{(11)}$. The relationships between their protein structure and digestibility are discussed below.

Despite an equivalent food intake and food protein content, diets based on faba bean pasta (FLT and FVHT) resulted in a higher rate of growth compared with diets based on gluten pasta (GLT and GVHT). This could be related to the higher essential amino acid content in FLT and FVHT in comparison to GLT and GVHT diets. The food efficiency ratios of faba bean diets observed here (approximately 0.33 ) were higher than those reported for diets containing $20 \%$ of purified chickpea and lentil proteins $(0 \cdot 21)^{(36)}$. Mixed wheat-legume meals could be an effective way to improve the low nutritional performance of diets with legume protein as the sole protein source and to achieve a similar protein efficiency as a casein control diet (CD).

Results of the present study support those of Torres et $a l .^{(13,14,20)}$, where protein efficiency ratio in pasta enriched with $10 \%$ legume (germinated or fermented pigeon pea, or $\alpha$-galactoside-free lupin flours) was $64-73 \%$ higher than that in wheat pasta. In our study, we were able to obtain a $77 \%$ increase in protein efficiency between FLT diet and GLT diet using a higher inclusion of legume flour (35 v. 10\%). The enhancement in protein efficiency ratio likely depends on legume type, enrichment level and preprocessing of the raw material.

ATTD was lower in rats fed faba bean than in rats fed gluten and casein diets. This was related to the higher faecal $\mathrm{N}$ loss in rats fed faba bean pasta diet compared with rats fed gluten and 
casein diets. The presence of trypsin inhibitors in legume diets leads to the formation of the irreversible trypsin enzyme-trypsin inhibitor complex, causing a drop in trypsin in the intestine ${ }^{(37)}$. Digestive enzymes are considered as an important source of endogenous $\mathrm{N}$, which can increase total faecal $\mathrm{N}$, thus decreasing ATTD. The amount of trypsin inhibitor in faba bean pasta $(0.61 \mathrm{mg} / \mathrm{g})$ measured in our previous work ${ }^{(19)}$, even though substantially reduced once the pasta is processed and cooked compared with raw legume flour $(7.8 \mathrm{mg} / \mathrm{g}$ faba bean flour ${ }^{(38)}$, likely caused a slight decrease in ATTD in the faba bean diets. The amount and type of fibres can also affect ATTD. Compared with gluten pasta diet, faba bean pasta diet provided an extra approximately $2 \cdot 2 \mathrm{~g} / 100 \mathrm{~g}$ diet of fibres (Table 2 ). The presence of fibres could play a role in increasing the excretion of endogenous N. Shah et al. ${ }^{(39)}$ reported that the incorporation of fibres (such as cellulose, pectin, lignin and guar gum) in a $10 \%$ casein diet reduced protein digestibility in growing rats by increasing endogenous $\mathrm{N}$ excretion (digestive gland secretion, desquamated cells from active replacement of gastrointestinal mucosal lining and a small amount of plasma proteins). Therefore, the digestion of faba bean pasta diet components likely required a higher production of endogenous enzymes due to the high level of constitutive fibres compared with gluten pasta diet. The specific type of fibre brought by legume flour could also affect faecal $\mathrm{N}$ and ATTD. Faba bean flour and wheat semolina contain $2 \cdot 36 \%^{(38)}$ and $1.54 \%$ (K Laleg and V Micard, unpublished results) of arabinose, respectively. Faba bean flour is richer in galactose compared with wheat semolina $(2.63 \mathrm{v}$. $0.69 \%$, dry basis). Galactose is a constituent of the arabinogalactans ${ }^{(38)}$. Whereas wheat semolina is richer in xylose compared with faba bean $(2.03 v \cdot 0 \cdot 74 \%$, dry basis). Xylose is a major component of arabinoxylans, the major polymers of wheat endosperm cell walls ${ }^{(40)}$. Van Laere et al. ${ }^{(41)}$ reported that arabinogalactans were generally fermented in vitro by twelve of the eighteen bacterial intestinal species studied, whereas arabinoxylans were only fermented by two intestinal bacteria with the same bacterial profile. Here, a different activity of gut bacteria could partially explain the increase in bacterial $\mathrm{N}$, contributing to a higher faecal $\mathrm{N}$ and a lower ATTD in faba bean pasta compared with gluten pasta diets

Aside from endogenous protein secretion, modifications of the dietary and non-dietary protein occur at the hindgut of the animal. The human large intestine exhibits substantial proteolytic activity, partly attributable to colonic microbes. In vitro and in vivo studies showed that proteolysis occurs rapidly, resulting in the formation of protein fermentation metabolites such as SCFA, ammonia and various phenolic acids ${ }^{(42,43)}$.

Here, total amount of dietary absorbed $\mathrm{N}$ (corrected faecal digestibility) was not significantly different in rats fed gluten and faba bean pasta diets. In all, $40 \%$ of the protein network structure in faba bean pasta was demonstrated to interact through weak bonds (mainly hydrogen, hydrophobic and electrostatic interactions), contrary to gluten pasta protein which is $90 \%$ linked by covalent bonds mainly disulphide. This structural difference resulted in a higher in vitro ileal protein hydrolysis $\left(17 \cdot 8 \%\right.$ ) of faba bean pasta ${ }^{(11)}$ - a difference not observed in vivo here. Among the few studies investigating the effect of enriching pasta with legumes on corrected faecal protein digestibility, only Torres et al. ${ }^{(13,14)}$ reported an increase $(6-13 \%)$ in faecal digestibility by substituting $10 \%$ of wheat semolina with pigeon pea flour. This enhancement in corrected faecal protein digestibility was most likely due to the pretreatment of legume flour (germination or fermentation) that could facilitate protein digestion.

Rats fed faba bean pasta diet showed lower urinary N compared with rats fed gluten pasta diet. At a similar protein intake, urinary $\mathrm{N}$ excretion may be affected by several parameters, chiefly essential amino acid composition ${ }^{(44)}$. The essential amino acid composition of FLT and FVHT proteins was closer to the $\mathrm{CD}$ and to the rat needs determined by National Research Council for growing rats ${ }^{(45)}$ compared with the GLT and GVHT proteins, notably for lysine, threonine, branched amino acids, histidine and tryptophan. This higher protein quality of faba bean pasta proteins could be responsible for the noticeable improvement in the efficiency of amino acid utilisation and in the $\mathrm{BV}$ of the diet compared with gluten pasta proteins that were poorer in some essential amino acids, for example, lysine.

In addition to essential amino acid composition, several studies reviewed by Jha \& Berrocoso ${ }^{(46)}$ have shown that the increase in dietary fibre can shift $\mathrm{N}$ from urinary to faecal excretion. The higher level of dietary fibre in FLT and FVHT diet could be another reason for the increase in faecal $\mathrm{N}$ excretion.

Rats fed faba bean pasta diet still present a higher urinary $\mathrm{N}$ and a lower protein utilisation compared with the rats fed CD. This could be related to the relatively lower quantity of essential amino acids in FLT and FVHT compared with the CD and to the increase in protein catabolism induced by certain bioactive compounds, notably trypsin inhibitors as demonstrated by Cenarruzabeitia et $a l .{ }^{(47)}$ in rats fed a field bean ( $V$. faba) diet.

Alongside essential amino acids, another factor that affects urinary $\mathrm{N}$ excretion and subsequent protein utilisation is the rate of protein digestion/absorption. Amino acids from a faster digested legume (soya) are directed toward deamination pathways more than milk amino acids ${ }^{(44)}$. This higher rate of the soya protein digestion/absorption process has been attributed to their faster intestinal transit compared with casein. In the acidic stomach conditions, legume (pea) protein aggregates are of smaller particle size $(80 \mu \mathrm{m})$ than casein $(2 \mathrm{~mm})$ and showed faster intestinal bioavailability than casein ${ }^{(48)}$. These data suggest that proteins in our faba bean pasta diet could be digested more rapidly than casein. A rapid absorption of amino acids is associated with both enhanced amino acid catabolism and transiently higher protein synthesis ${ }^{(2,44,49)}$. The fact that faba bean pasta protein acts as a rapidly digested protein could be beneficial in specific subpopulations such as older people. Muscle protein synthesis is altered in older people, mainly due to a decrease in the specific anabolic response to amino acids. It has been suggested that protein synthesis in older people could be resistant to amino acid availability, and that high aminoacidemia is needed to improve postprandial protein gain ${ }^{(50,51)}$. Hence, a fast digestive protein, like whey protein, was more efficient than an isonitrogeneous casein protein in increasing leucine balance and protein utilisation in old men ${ }^{(52)}$. This improvement in protein gain was related to potentially higher hyperaminoacidaemia induced by rapid digestion of whey protein in comparison to casein. Thus, with respect to its potentially faster kinetics of digestion, faba bean-enriched pasta 
could be a promising way to increase aminoacidaemia and subsequent postprandial protein retention in older subjects

Rats fed FLT and FVHT showed a higher level of global growth parameters (rate of growth, liver and muscle weights) compared with GLT and GVHT, which was related to the higher protein retention with FLT and FVHT diets. Branched amino acids were also reported to be able to dose-dependently stimulate muscle protein synthesis in growing rats ${ }^{(53,54)}$. The higher (9-10\%) branched chain amino acid content in faba bean pasta diet compared with gluten pasta diet could be involved in higher muscle protein synthesis in rats fed faba bean. Compared with the CD, the faba bean pasta diet led to a slightly lower LM and liver weight (ratioed to body weight) associated with the relatively lower protein utilisation and branched amino acids. Rate of animal growth between these two groups was nevertheless equivalent because of the higher FM in faba bean group rats compared with the $\mathrm{CD}$ group rats. Huang et al. ${ }^{(55)}$ and Iritani et $a l .{ }^{(56)}$ also reported a $10-13 \%$ decrease in liver weight in rats fed $18-20 \%$ gluten or soya proteins compared with rats fed casein. Alonso et al. ${ }^{(57)}$ reported that in addition to the liver, both gastrocnemius and tibialis anterior muscle weight and protein content were also reduced after consumption of a approximately $13 \%$ protein diet based on raw or extruded pea compared with a casein diet. This was linked to the amino acid deficiencies in the diet and to the action of anti-nutritional factors. We did not observe any effect of faba bean pasta diet consumption on muscle weight or protein content, likely due to a better balanced amino acid composition in the mixed protein source food (compared with the legume alone) and to the reduction of certain bioactive compounds (trypsin inhibitors, $\alpha$-galactosides) by pasta processing and cooking steps.

Fasting blood albumin and total protein were observed to be lower with GLT and VHT than with FLT, FVHT and CD. Albumin is the major secretory protein synthetised by the liver ${ }^{(58)}$. Hypoalbuminaemia is the result of both inflammation and nutritional stress related to inadequate protein and energy intake ${ }^{(59)}$. In our study, feeding GLT and GVHT did not increase blood inflammatory markers (orosomucoid, fibrinogen and MCP-1). As all diets were isoenergetic, the quality of dietary protein was probably involved in decreasing the plasma albumin. Indeed, the removal of certain essential amino acids (leucine, isoleucine and tryptophan) from a rat liver culture medium induced a decrease in total protein and albumin liver synthesis ${ }^{(58)}$. Thus, the dietary protein and its amino acid composition were likely at the origin of this low plasma albumin in the GLT and GVHT groups.

Eating pasta diets (except GVHT) increased FM compared with eating the CD. Glucose was also slightly increased under faba bean pasta diet, and tended to be higher under gluten pasta diet than under the $\mathrm{CD}$ diet $(P=0 \cdot 07)$. This slightly higher glucose content in rats eating pasta diets could stem from the different structures of starch within pasta and CD. The pasta was cooked until total starch gelatinisation, whereas the maize starch used to prepare the $\mathrm{CD}$ was in its native ungelatinised form. Highly gelatinised starch is more available to the digestive enzymes, causing an increase in the rate of starch digestion ${ }^{(60)}$. Consequently higher plasma glucose in rats eating pasta diets probably led to higher adipose tissue deposition through de novo lipogenesis. Blood leptin was positively correlated with body FM, adipose tissue weight and blood TAG content. Leptin contributes to the regulation of body weight by modulating appetite and energy expenditure ${ }^{(61)}$. It stimulates fatty acid oxidation and prevents lipid accumulation in non-adipose tissues ${ }^{(62)}$. Obese humans showed higher leptin levels, suggesting a resistance to its action $^{(63)}$. The increase in leptin content observed here could be related to the higher adipose tissue, as demonstrated in mice by Frederich et al. ${ }^{(64)}$ This increase in leptin and blood glucose was more pronounced after feeding faba bean pasta than when fed gluten pasta diet, and it was also accompanied by a higher blood insulin and orosomucoid inflammatory marker levels in rats receiving faba bean pasta than those receiving gluten pasta diet. Orosomucoids are acute-phase plasma proteins synthesised by the liver. Inflammatory disorders can increase the concentration of these compounds ${ }^{(65)}$. The increase in orosomucoids could indicate that FLT and FVHT consumption could have induced an inflammatory response. Although faba bean pasta diets contained higher fibres shown to decrease inflammation ${ }^{(66,67)}$, and a more adequate essential amino acids profile for rat growth compared with gluten pasta (based on the National Research Council requirement) ${ }^{(45)}$, it still presents limiting sulphur amino acids that could be responsible for the inflammatory disorders observed in rats fed faba bean ${ }^{(33,68)}$

The second objective of our study was to evaluate whether the use of VHT drying during pasta processing affects protein digestibility and retention and the subsequent growth, nutritional and metabolic parameters. Among all the end points determined, VHT drying only increased faecal $\mathrm{N}$ and decreased faecal protein digestibility in rats fed gluten pasta diet. This difference in the digestive behaviour of GVHT could not be attributed to the amount of covalent interactions or to the conformation of the pasta protein, as we previously showed ${ }^{(11)}$ that proteins in gluten pasta dried at LT and VHT had the same amount of covalently linked protein and the same secondary conformation ${ }^{(11)}$. The low faecal protein digestibility of GVHT could be attributed to some Maillard products. Indeed, Maillard reactions occur during high-temperature treatment of wheat pasta and were shown to decrease the in vitro ileal release of amino acids ${ }^{(69)}$. In addition, in line with our results, the consumption of Maillard-rich products was shown to increase faecal $\mathrm{N}$ excretion in humans and decrease apparent and true protein digestibility without effect on protein utilisation or serum biochemical variables ${ }^{(70)}$. Here, among Maillard products, CML was higher in all VHT pasta diets, and its increase was greater with gluten pasta (79\%) than with faba bean pasta (67\%) diets, which could explain the lower effect of VHT drying on faba bean pasta diet digestibility.

In conclusion, this study clearly demonstrated that consumption of mixed wheat-legume pasta diet leads to improved faecal protein digestibility and protein utilisation, muscle weight, blood nutritional markers and rat growth compared with the classical isoprotein gluten-wheat pasta diet consumed alone in growing rats. Combining wheat with legume as a complementary plant source led to a more adequate essential amino acid profile for growth processes that likely explains the improved nutritional and growth parameters. The weakening in the force of proteinprotein interactions induced by enriching wheat pasta with faba beans did not affect corrected faecal protein digestibility. We also 
showed that the high drying temperature could decrease amino acid bioavailability through structural protein modifications induced by the formation of certain Maillard products.

Mixed wheat-legume pasta diet led to much close nutritional and growth parameters as a high-nutritional-value reference protein, that is, casein. In addition, the proteins in faba beanenriched pasta diet likely acted as relatively rapidly digested protein in the digestive tract compared with casein protein. This physicochemical behaviour of legume pasta protein could be involved in modulating the rate of protein digestion, affecting the whole-body protein metabolism. This characteristic would be beneficial to promote protein deposition in settings marked by an age-related loss of muscle.

\section{Acknowledgements}

The authors thank GEMEF industries (Aix-en-Provence, France) for kindly providing faba bean flour and T.-M. Lasserre and J. Bonicel (UMR IATE, Montpellier, France) for their technical assistance.

This work was carried out with financial support from the Auvergne regional council and under the VEGAGE project that received financial support from 'Institut Carnot-Qualiment'.

S. W., V. M., K. L., J. S., Y. B. conceived and designed the experiments. K. L., A. B., J. S., V. P., P. D., C. G., S. W. and V. M. performed the experiments. F. J. T., A. G. and M. H. were involved in the analysis of CML. K. L., V. M. and S. W. analysed the data and performed statistical analysis. K. L. wrote the paper. S. W. acquired the funding.

The authors declare that there are no conflicts of interest.

\section{Supplementary material}

For supplementary material/s referred to in this article, please visit https://doi.org/10.1017/S0007114518003586

\section{References}

1. Friedman $M$ (1996) Nutritional value of proteins from different food sources. A review. J Agric Food Chem 44, 6-29.

2. Boirie Y, Dangin M, Gachon P, et al. (1997) Slow and fast dietary proteins differently modulate postprandial protein accretion. Proc Natl Acad Sci U S A 94, 14930-14935.

3. Bohrer BM (2017) Review: nutrient density and nutritional value of meat products and non-meat foods high in protein. Trends Food Sci Technol 65, 103-112.

4. Sosulski FW \& Imafidon GI (1990) Amino-acid-composition and nitrogen-to-protein conversion factors for animal and plant foods. J Agric Food Chem 38, 1351-1356.

5. Rouilly A, Orliac O, Silvestre F, et al. (2001) DSC study on the thermal properties of sunflower proteins according to their water content. Polymer 42, 10111-10117.

6. Gerber PJ, Steinfeld H, Henderson B, et al. (2013) Tackling Climate Change Through Livestock - A Global Assessment of Emissions and Mitigation Opportunities. Rome: Food and Agriculture Organization of the United Nations.

7. Bernstein AM, Sun Q, Hu FB, et al. (2010) Major dietary protein sources and risk of coronary heart disease in women. Circulation 122, 876-883.

8. Greffeuille V, Marsset-Baglieri A, Molinari N, et al. (2015) Enrichment of pasta with faba bean does not impact glycemic or insulin response but can enhance satiety feeling and digestive comfort when dried at very high temperature. Food Funct 6, 2996-3005.

9. Jenkins DJA, Wolever TMS, Jenkins AL, et al. (1983) Glycemic response to wheat products - reduced response to pasta but no effect of fiber. Diabetes Care 6, 155-159.

10. Bjorck I, Liljeberg H \& Ostman E (2000) Low glycaemicindex foods. Br J Nutr 83, S149-S155.

11. Laleg K, Barron C, Sante-Lhoutellier V, et al. (2016) Protein enriched pasta: structure and digestibility of its protein network. Food Funct 7, 1196-1207.

12. Gimenez MA, Drago SR, De Greef D, et al. (2012) Rheological, functional and nutritional properties of wheat/broad bean (Vicia faba) flour blends for pasta formulation. Food Chem 134, 200-206.

13. Torres A, Frias J, Granito M, et al. (2006) Fermented pigeon pea (Cajanus cajan) ingredients in pasta products. J Agric Food Chem 54, 6685-6691.

14. Torres A, Frias J, Granito M, et al. (2007) Germinated Cajanus cajan seeds as ingredients in pasta products: chemical, biological and sensory evaluation. Food Chem 101, 202-211.

15. Duranti M (2006) Grain legume proteins and nutraceutical properties. Fitoterapia 77, 67-82.

16. Piecyk M, Wolosiak R, Druzynska B, et al. (2012) Chemical composition and starch digestibility in flours from Polish processed legume seeds. Food Chem 135, 1057-1064.

17. Petitot M, Brossard C, Barron C, et al. (2009) Modification of pasta structure induced by high drying temperatures. Effects on the in vitro digestibility of protein and starch fractions and the potential allergenicity of protein hydrolysates. Food Chem 116, 401-412.

18. De Zorzi M, Curioni A, Simonato B, et al. (2007) Effect of pasta drying temperature on gastrointestinal digestibility and allergenicity of durum wheat proteins. Food Chem 104, 353-363.

19. Laleg K, Barron C, Cordelle S, et al. (2016) How the structure, nutritional and sensory attributes of pasta made from legume flour is affected by the proportion of legume protein. Lebenson Wiss Technol 79, 471-478.

20. Torres A, Frias J, Granito M, et al. (2007) Chemical, biological and sensory evaluation of pasta products supplemented with alpha-galactoside-free lupin flours. J Sci Food Agric 87, 74-81.

21. AACC (1999) Method 44-01.01 Calculation of Percent Moisture, AACC Methods, 11th ed. St Paul, MN: AACC International.

22. French Standardisation Agency (AFNOR) (1981) NF V03720. Céréales et produits de mouture. Détermination des cendres (Cereals and grinding products. Ash determination). www.boutique.afnor.org/normes

23. AACC (2000) Method 76-13.01 Total Starch Assay Procedure (Megazyme amyloglucosidase/alpha-Amylase Method), AACC Methods, 11th ed. St. Paul, MN: AACC International.

24. French Standardisation Agency (AFNOR) (1970) NF V 03-050. Directives générales pour le dosage de l'azote avec minéralisation selon la méthode de Kjeldahl (General guidelines for the determination of nitrogen with mineralisation according to the Kjeldahl method). www.boutique.afnor.org/normes

25. Arrêté du 25 juillet 1986 relatif à la méthode officielle d'analyse pour la détermination de la teneur en fibres alimentaires totales des produits au son (Decree of 25 July 1986 on the official method for the determination of total dietary fibre of bran products).

26. NF ISO 6492. Mars 2011. Aliments des animaux. Détermination de la teneur en matière grasse (NF ISO 6492. March 2011. Animal foods. Determination of the fat content).

27. Arrêté du 8 septembre 1977 relatif aux méthodes officielles d'analyse des produits diététiques et de régime. Article 2: Détermination de la teneur en lipides totaux (Decree of 8 September 1977 on official methods of analysis of dietary products and diet. Article 2: Determination of total lipid content). 
28. AOAC (1990) Method no. 985.29. Total dietary fiber. In Official Methods of Analysis of the Association of Official Analytical Chemists, 15th ed. Washington, DC: Association of Official Analytical Chemists.

29. European Commission (2009) Commission Regulation (EC) No 152/2009 of 27 January 2009 laying down the methods of sampling and analysis for the official control of feed. Off J Eur Union L 54/24.

30. Niquet-Leridon C \& Tessier FJ (2011) Quantification of N-epsiloncarboxymethyl-lysine in selected chocolate-flavoured drink mixes using high-performance liquid chromatography-linear ion trap tandem mass spectrometry. Food Chem 126, 655-663.

31. Proll J, Petzke KJ, Ezeagu IE, et al. (1998) Low nutritional quality of unconventional tropical crop seeds in rats. J Nutr 128, 2014-2022.

32. Galland L (2010) Diet and inflammation. Nutr Clin Pract 25, 634-640.

33. Bao XY, Feng ZM, Yao JM, et al. (2017) Roles of dietary amino acids and their metabolites in pathogenesis of inflammatory bowel disease. Mediators Inflamm 2017, 6869259.

34. Giugliano D, Ceriello A \& Esposito K (2006) The effects of diet on inflammation - emphasis on the metabolic syndrome. $J \mathrm{Am}$ Coll Cardiol 48, 677-685.

35. Salehi-Abargouei A, Saraf-Bank S, Bellissimo N, et al. (2015) Effects of non-soy legume consumption on C-reactive protein: a systematic review and meta-analysis. Nutrition 31, 631-639.

36. Boualga A, Prost J, Taleb-Senouci D, et al. (2009) Purified chickpea or lentil proteins impair VLDL metabolism and lipoprotein lipase activity in epididymal fat, but not in muscle, compared to casein, in growing rats. Eur J Nutr 48, 162-169.

37. VidalValverde C, Frias J, DiazPollan C, et al. (1997) Influence of processing oil trypsin inhibitor activity of faba beans and its physiological effect. J Agric Food Chem 45, 3559-3564.

38. Laleg K, Cassan D, Barron C, et al. (2016) Structural, culinary, nutritional and anti-nutritional properties of high protein, gluten free, 100\% legume pasta. PLOS ONE 11, e0160721.

39. Shah N, Atallah MT, Mahoney RR, et al. (1982) Effect of dietary fiber components on fecal nitrogen-excretion and proteinutilization in growing-rats. J Nutr 112, 658-666.

40. Saulnier L, Sado PE, Branlard G, et al. (2007) Wheat arabinoxylans: exploiting variation in amount and composition to develop enhanced varieties. J Cereal Sci 46, 261-281.

41. Van Laere KMJ, Hartemink R, Bosveld M, et al. (2000) Fermentation of plant cell wall derived polysaccharides and their corresponding oligosaccharides by intestinal bacteria. J Agric Food Chem 48, 1644-1652.

42. Cummings JH \& Englyst HN (1987) Fermentation in the human large-intestine and the available substrates. Am J Clin Nutr 45, 1243-1255.

43. Gilbert MS, Ijssennagger N, Kies AK, et al. (2018) Protein fermentation in the gut; implications for intestinal dysfunction in humans, pigs, and poultry. Am J Physiol Gastrointest Liver Physiol 315, G159-G170.

44. Bos C, Metges CC, Gaudichon C, et al. (2003) Postprandial kinetics of dietary amino acids are the main determinant of their metabolism after soy or milk protein ingestion in humans. J Nutr 133, 1308-1315.

45. National Research Council (1995) Nutrient Requirements of Laboratory Animals, 4th revised ed., pp. 22-27. Washington, DC: National Academies of Science.

46. Jha R \& Berrocoso JFD (2016) Dietary fiber and protein fermentation in the intestine of swine and their interac \tive effects on gut health and on the environment: a review. Animal Feed Sci Technol 212, 18-26.

47. Cenarruzabeitia MN, Santidrian S, Bello J, et al. (1979) Effect of raw field bean (Vicia faba) on amino-acid-degrading enzymes in rats and chicks. Nutr Metab 23, 203-210.
48. Overduin J, Guérin-Deremaux L, Wils D, et al. (2015) NUTRALYS ${ }^{\circledR}$ pea protein: characterization of in vitro gastric digestion and in vivo gastrointestinal peptide responses relevant to satiety. Food Nutr Res 59, 25622.

49. Dangin M, Boirie Y, Garcia-Rodenas C, et al. (2001) The digestion rate of protein is an independent regulating factor of postprandial protein retention. Am J Physiol Endocrinol Metab 280, E340-E348.

50. Volpi E, Ferrando AA, Yeckel CW, et al. (1998) Exogenous amino acids stimulate net muscle protein synthesis in the elderly. J Clin Invest 101, 2000-2007.

51. Mosoni L, Valluy MC, Serrurier B, et al. (1995) Altered response of protein-synthesis to nutritional state and endurance training in old rats. Am J Physiol Endocrinol Metab 268, E328-E335.

52. Dangin M, Guillet C, Garcia-Rodenas C, et al. (2003) The rate of protein digestion affects protein gain differently during aging in humans. J Physiol 549, 635-644.

53. Li JB \& Jefferson LS (1978) Influence of amino-acid availability on protein turnover in perfused skeletal-muscle. Biochim Biophys Acta 544, 351-359.

54. Garlick PJ \& Grant I (1988) Amino-acid infusion increases the sensitivity of muscle protein-synthesis invivo to insulin - effect of branched-chain amino-acids. Biochem J 254, 579-584.

55. Huang YS, Cunnane SC \& Horrobin DF (1986) Effect of different dietary proteins on plasma and liver fatty-acid compositions in growing-rats. Proc Soc Exp Biol Med 181, 399-403.

56. Iritani N, Nagashima K, Fukuda H, et al. (1986) Effects of dietary proteins on lipogenic enzymes in rat-liver. $J$ Nutr 116, 190-197.

57. Alonso R, Grant G, Fruhbeck G, et al. (2002) Muscle and liver protein metabolism in rats fed raw or heat-treated pea seeds. J Nutr Biochem 13, 611-618.

58. Hutson SM, Stinsonfisher C, Shiman R, et al. (1987) Regulation of albumin synthesis by hormones and amino-acids in primary cultures of rat hepatocytes. Am J Physiol 252, E291-E298.

59. Don BR \& Kaysen G (2004) Serum albumin: relationship to inflammation and nutrition. Semin Dial 17, 432-437.

60. Holm J, Lundquist I, Bjorck I, et al. (1988) Degree of starch gelatinization, digestion rate of starch in vitro, and metabolic response in rats. Am J Clin Nutr 47, 1010-1016.

61. Yadav A, Kataria MA, Saini V, et al. (2013) Role of leptin and adiponectin in insulin resistance. Clin Chim Acta 417, 80-84.

62. Shimabukuro M, Koyama K, Chen GX, et al. (1997) Direct antidiabetic effect of leptin through triglyceride depletion of tissues. Proc Natl Acad Sci U S A 94, 4637-4641.

63. Considine RV, Sinha MK, Heiman ML, et al. (1996) Serum immunoreactive leptin concentrations in normal-weight and obese humans. N Engl J Med 334, 292-295.

64. Frederich RC, Hamann A, Anderson S, et al. (1995) Leptin levels reflect body lipid-content in mice - evidence for dietinduced resistance to leptin action. Nat Med 1, 1311-1314.

65. Liaskou E, Wilson DV \& Oo YH (2012) Innate immune cells in liver inflammation. Mediat Inflamm 2012, 949157.

66. Bernaud FSR, Beretta MV, do Nascimento C, et al. (2014) Fiber intake and inflammation in type 1 diabetes. Diabetol Metab Syndr 6, 66.

67. Ajani UA, Ford ES \& Mokdad AH (2004) Dietary fiber and C-reactive protein: findings from National Health and Nutrition Examination Survey Data. J Nutr 134, 1181-1185.

68. Chiba T, Suzuki S, Sato Y, et al. (2016) Evaluation of methionine content in a high-fat and choline-deficient diet on body weight gain and the development of non-alcoholic steatohepatitis in mice. PLOS ONE 11, e0164191.

69. Stuknyte M, Cattaneo S, Pagani MA, et al. (2014) Spaghetti from durum wheat: effect of drying conditions on heat damage, ultrastructure and in vitro digestibility. Food Chem 149, 40-46.

70. Seiquer I, Diaz-Alguacil J, Delgado-Andrade C, et al. (2006) Diets rich in Maillard reaction products affect protein digestibility in adolescent males aged 11-14 y. Am J Clin Nutr 83, 1082-1088. 